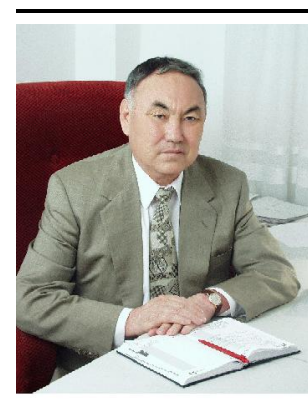

УДК 631.145(574)

https://doi.org/10.47612/978-985-7149-55-1-2020-100-103

Гани Калиев, академик, доктор экономических наук, профессор, Президент Академии сельскохозяйственных наук Республики

Казахстан, г. Алматы, Казахстан

Алтынбек Молдашев, доктор экономических наук, профессор, главный научный сотрудник

ТОО «Казахский научно-исследовательский институт экономики АПК и развития сельских территорий», г. Алматы, Казахстан

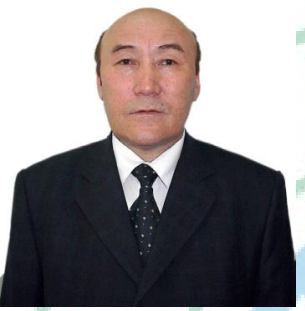

\title{
Актуалыьные проблемы аграрного производства в Казахстане
}

Благодаря проводимой аграрной политике в Казахстане наблюдается рост производства продукции сельского хозяйства в зависимости от вида от $29 \%$ до 3,4 раза. Так, в 2019 г. по сравнению с 2000 г. выросло производство зерна на 50 \% (с 11,6 до 20,3 млн т), овощебахчевых культур - в 3,4 раза (с 1,9 до 6,7 млн т), картофеля - в 2,3 раза (с 1,7 до 3,9 млн т), мяса - на $80 \%$ (с 0,6 до 1,1 млн т), молока - на $56 \%$ (с 3,7 до 5,8 млн т), плодов и ягод - на $83 \%$ ( с 0,2 до 0,37 млн т) (табл. 1).

В животноводстве наблюдается рост поголовья животных: КРС - на 81,1 \% (с 4,1 до 7,4 млн гол.), лошадей в 2,9 раза (с 0,97 до 2,8 млн гол.), овец и коз - на 91,9\% (с 9,9 до 19,1 млн гол.), птицы - в 2,5 раза (с 19,7 до 45,0 млн гол.).

Несмотря на то что наблюдается рост производства продукции по сравнению с 2000 г., фактическое потребление продуктов питания на душу населения еще значительно ниже их научно обоснованных норм, особенно это видно по картофелю (всего 48,6 \% от нормы), овощам и бахчевым $(63,1)$, фруктам и ягодам $(56,7)$, молоку $(86,8)$, яйцам $(66,2 \%)$ (табл. 2).

В связи с этим к 2025 г. по данным видам продукции необходимо наращивание производства. Отдельные продукты, не производимые в Казахстане, в допустимых объемах могут импортироваться из других государств.

Сегодня одним из приоритетных направлений развития агропромышленного комплекса республики является переработка сельскохозяйственной продукции. Несмотря на позитивные тенденции и принимаемые меры государственной поддержки, доля переработки сельхозпродуктов в общем объеме производства остается низкой. Например, переработка мяса составляет около $24 \%$ общего объема производства, молока - 30, зерна - 27, плодов и овощей $-7 \%$. Это подтверждает необходимость развития глубокой переработки сельскохозяйственной продукции, в связи с чем считаем целесообразным принятие программы по модернизации предприятий перерабатывающей и пищевой промышленности.

Существенной проблемой аграрного сектора является состояние его материально-технической базы. Парк сельскохозяйственной техники значительно сократился, о чем свидетельствуют данные таблицы 3.

Имеет место большой износ техники и технологического оборудования, который, по оценкам экспертов, достигает более 70 \%. Ежегодные темпы обновления

Таблица 1. Динамика производства продукции сельского хозяйства

\begin{tabular}{|c|c|c|c|c|c|}
\hline \multirow{3}{*}{ Показатели } & \multirow{2}{*}{2000 г. } & \multirow{2}{*}{2018 г. } & \multirow{2}{*}{2019 г. } & \multicolumn{2}{|c|}{2019 г.в \% к } \\
\hline & & & & 2000 г. & 2018 г. \\
\hline & 402,0 & 4410,0 & 5200,0 & 129,3 & 117,9 \\
\hline $\begin{array}{l}\text { Производство во всех категориях хозяйств, тыс. т: } \\
\text { зерна }\end{array}$ & $-11565,0$ & 20273,7 & 17428,9 & 150,7 & 86,0 \\
\hline картофеля & 1692,6 & 3807,0 & 3912,1 & 231,1 & 102,7 \\
\hline овощей и бахчевых & 1965,2 & 624,4 & 6737,3 & 342,8 & 108,2 \\
\hline плодов и ягод & 201,7 & 341,2 & 369,1 & 183,0 & 108,2 \\
\hline мяса & 622,6 & 1059,4 & 1120,6 & 180,0 & 105,8 \\
\hline молока & 3730,2 & 5686,2 & 5819,3 & 156,0 & 102,3 \\
\hline яиц & 1692,2 & 5591,4 & 5531,4 & 326,8 & 98,9 \\
\hline семян масличных & 140,1 & 2693,6 & 2583,6 & 1844,1 & 95,9 \\
\hline $\begin{array}{l}\text { Поголовье сельскохозяйственных животных во всех } \\
\text { категориях хозяйств, тыс. гол.: } \\
\text { КРС }\end{array}$ & 4107,0 & 7150,9 & 7436,4 & 181,1 & 104,0 \\
\hline в том числе коровы & 2015,0 & 3576,5 & 3769,7 & 187,1 & 105,4 \\
\hline овцы и козы & 9981,0 & 18699,1 & 19155,7 & 191,9 & 102,4 \\
\hline свиньи & 1076,0 & 798,7 & 813,3 & 75,6 & 101,8 \\
\hline лошади & 976,0 & 2646,5 & 2852,2 & 292,2 & 105,8 \\
\hline верблюды & 98,0 & 207,6 & 216,3 & 220,7 & 104,2 \\
\hline птица & 19,7 & 44,3 & 45,0 & 228,4 & 101,6 \\
\hline
\end{tabular}


Таблица 2. Уровень потребления основных видов продовольствия в 2018 г., кг

\begin{tabular}{|l|c|c|c|}
\hline \multicolumn{1}{|c|}{ Продукция } & $\begin{array}{c}\text { Научно обоснованные нормы } \\
\text { потребления на душу } \\
\text { населения }\end{array}$ & $\begin{array}{c}\text { Фактическое } \\
\text { потребление на душу } \\
\text { населения }\end{array}$ & $\begin{array}{c}\text { Отношение фактического } \\
\text { потребления к нормативному, } \\
\%\end{array}$ \\
\hline Хлебопродукты, зерно & 109,0 & 138,5 & 127,0 \\
\hline Картофель & 100,0 & 48,6 & 48,6 \\
\hline Овощи и бахчевые & 149,0 & 94,1 & 63,1 \\
\hline Фрукты и ягоды & 132,0 & 74,9 & 147,7 \\
\hline Масло растительное & 13,0 & 19,2 & 86,8 \\
\hline Молоко и молочные продукты & 301,0 & 261,2 & 99,4 \\
\hline Мясо всех видов и мясопродукты & 78,4 & 77,9 & 66,2 \\
\hline Яйца & 292,0 & 193,3 & 94,3 \\
\hline Рыба & 14,0 & 13,2 & \\
\hline
\end{tabular}

Таблица 3. Состояние машинно-тракторного парка в 1991-2019 гг., тыс. шт.

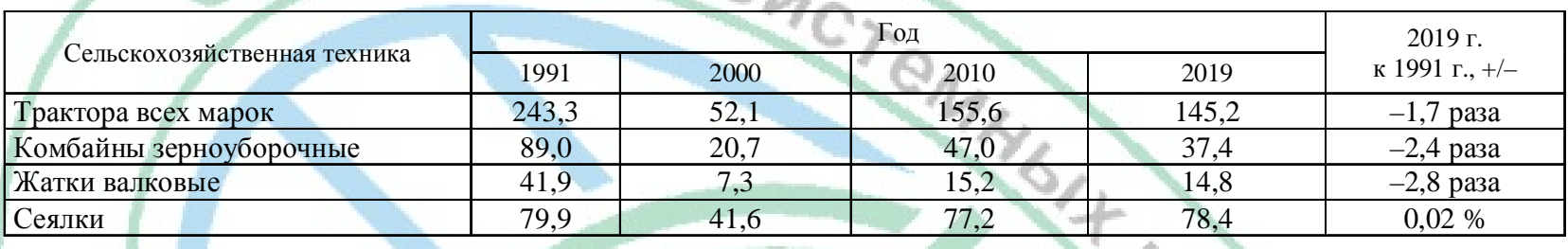

техники крайне низкие - менее $3,5 \%$ при оптимальном 6-7\%. Главная причина такой ситуации - неразвитость сельскохозяйственного и тракторного машиностроения в республике. Техника в основном закупается в странах ближнего (Россия, Беларусь, Украина) и дальнего зарубежья (Германия, США, КНР, Израиль и др.). Количество закупаемой техники из-за ее дороговизны крайне мало и не позволяет хозяйствам, имеющим низкие доходы и прибыль, обновлять парк сельскохозяйственных машин более быстрыми темпами. Вышесказанное подчеркивает необходимость создания совместных предприятий или филиалов Беларуси, России и других развитых зарубежных стран по типу консорциумов.

По расчетам казахстанских ученых, для укрепления материально-технической базы сельского хозяйства, строительства животноводческих ферм, перерабатывающих предприятий, предприятий для хранения сельскохозяйственной продукции и другой инфраструктуры потребуется в ближайшие годы инвестиций в объеме около 8 трлн тенге, что в 1,6 раза превышает стоимость валовой продукции сельского хозяйства за 2019 г.

Следующая важнейшая проблема аграрного сектоpa - уровень государственной поддержки. В настоящее время экономика республики развивается в условиях ЕАЭС и ВТО, то есть интегрировалась в мировое экономическое пространство, а следовательно, и уровень поддержки сельского хозяйства должен быть не ниже не только развитых государств, но и стран - участников ЕАЭС. Однако Казахстан значительно уступает своим ведущим партнерам по интеграции Беларуси и России и казахстанская продукция на общем рынке менее конкурентоспособна. По сравнению с Россией на 1 га сельхозугодий в Казахстане выделяется в 1,9 раза меньше субсидий, а на посевы - в 1,4 раза (табл. 4).

Являясь членом ВТО, Казахстан имеет возможность получения прямой поддержки сельского хозяйства в размере $8,5 \%$ к стоимости валовой продукции, а в настоящее время $-5,8 \%$. Поэтому есть потенциал наращивания господдержки аграрного сектора.

Одним из главных приоритетов государственной политики должно стать развитие горизонтальной кооперации, основанной на объединении мелкоземельных крестьянских хозяйств в единые севооборотные массивы смежных землепользований для совместной обработки земель. В настоящее время число крестьянских хозяйств с площадью до 50 га составляет 64,1 \% от их общей численности (табл. 5). В зоне орошаемого земледелия южного региона дифференциация хозяйств еще более значительна. Так, например, из 10,0 тыс. крестьянских хозяйств Енбекшиказахского района Алматинской области 9, 1 тыс. ед., или 90,5 \%, занимают площадь пашни до 10 га, Махтааральского и Сайрамского районов Южно-Казахстанской области - соответственно 92 и 90,5\%. Данные таблицы подтверждают объективную необходимость объединения мелких фермеров в более крупные формирования кооперативного типа.

Основные проблемы, сдерживающие развитие сельхозкооперации в Республике Казахстан:

- при создании кооперативов значительный акцент был сделан только на объединение ЛПХ, а не на кооперацию мелких и средних крестьянских хозяйств, имеющих возможность совместного производства сельхозпродукции

Таблица 4. Государственная поддержка развития сельского хозяйства России и Казахстана, 2019 г.

\begin{tabular}{|l|c|c|}
\hline \multicolumn{1}{|c|}{ Показатели } & Россия & Казахстан \\
\hline Валовая продукция сельского хозяйства, млрд долл. США & 91,3 & 13,7 \\
\hline Объем субсидий, млрд долл. США & 4,8 & 0,8 \\
\hline Удельный вес субсидий в валовой продукции сельского хозяйства, \% & 5,3 & 5,8 \\
\hline Объем субсидий на 1 га сельхозугодий, долл. США & 21,8 & 11,7 \\
\hline Объем субсидий на 1 га посевов, долл. США & 60,0 & 41,8 \\
\hline
\end{tabular}


Таблица 5. Структура землепользования крестьянских хозяйств, имеющих сельхозугодия в составе выделенных групп по регионам страны

\begin{tabular}{|c|c|c|c|c|c|c|c|c|c|}
\hline \multirow[b]{2}{*}{ Регион } & \multirow{2}{*}{$\begin{array}{c}\text { Количество крестьян- } \\
\text { ских хозяйств, имею- } \\
\text { щих сельхозугодия, } \\
\text { тыс. ед. }\end{array}$} & \multicolumn{2}{|c|}{ До 50 га } & \multicolumn{2}{|c|}{ От 51 до 200 га } & \multicolumn{2}{|c|}{ От 201 до 500 га } & \multicolumn{2}{|c|}{ Свыше 500 га } \\
\hline & & тыс. ед. & $\%$ & тыс. ед. & $\%$ & тыс. ед. & $\%$ & тыс. ед. & $\%$ \\
\hline Республика Казахстан & 153,4 & 98,3 & 64,1 & 22,6 & 14,7 & 14,0 & 9,1 & 18,5 & 12,1 \\
\hline Северный & 13,8 & 1,3 & 9,4 & 4,6 & 33,3 & 3,5 & 25,4 & 4,4 & 31,9 \\
\hline Западный & 10,7 & 1,1 & 10,3 & 1,9 & 17,8 & 2,1 & 19,6 & 5,6 & 52,3 \\
\hline Восточный & 11,2 & 4,0 & 35,7 & 2,8 & 25,0 & 1,6 & 14,3 & 2,8 & 25,0 \\
\hline Центральный & 6,0 & 0,2 & 3,3 & 1,0 & 16,7 & 1,4 & 23,3 & 3,4 & 56,7 \\
\hline Южный & 111,7 & 91,7 & 82,1 & 12,3 & 11,0 & 5,4 & 4,8 & 2,3 & 2,1 \\
\hline
\end{tabular}

путем эффективного использования имеющегося ресурсного потенциала (земельных, производственных, трудовых ресурсов и др.);

- объединение только ЛПХ, не имеющих земли, поголовья скота, финансовых средств на покупку кормов и других средств производства, было лишь ради получения льготного кредита по 3-6 млн тенге под 6 \% годовых по условиям Фонда финансовой поддержки сельского хозяйства на покупку скота. Все это способствовало росту количества созданных кооперативов без подтверждения результатов их деятельности по увеличению объемов производства, не говоря об их качестве.

Исходя из вышеизложенного рекомендуется ориентироваться не на объединение ЛПХ, а на горизонтальную кооперацию мелких и средних крестьянских хозяйств, имеющих возможность прогрессивных технологий выращивания сельхозпродукции для сохранения плодородия земли, использования единой системы научно обоснованных севооборотов, что позволит повысить объемы производства продукции, продуктивность животных, урожайность сельхозкультур и, соответственно, производительность труда, конкурентоспособность отечественной продукции АПК.

Еще один немаловажный вопрос - освоение отдаленных пастбищных угодий. Для решения этой проблемы необходимо создание укрупненных хозяйственных субъектов по овцеводству и коневодству на основе использования пустующих земельных угодий, которые находятся в землях запаса. Для их освоения необходимо достаточное водообеспечение, возможное за счет подъема подземных вод с использованием возобновляемых источников энергии. Учеными-аграриями по данному направлению осуществлены два пилотных проекта в Жамбылской и Карагандинских областях. Освоение отдаленных угодий позволит создать рабочие места и условия для реурбанизации, что характерно для современной мировой тенденции.

По проблемам повышения продуктивности сельскохозяйственных животных приоритетным направлением следует рассматривать разведение отечественных пород скота, более приспособленных к резкоконтинентальным природно-климатическим и кормовым условиям республики на основе использования высокоценной генетической продукции зарубежной селекции, совершенствования технологий ведения животноводства. При этом необходимо в регионах страны возобновить деятельность государственных племенных станций по снабжению семенем высокопродуктивных производителей сельскохозяйственных животных.

Для роста конкурентоспособности аграрного производства необходимо повышение эффективности научных исследований, обеспечение научных учреждений достаточным уровнем финансирования. Результаты научных исследований, их кадровое обеспечение, прежде всего, зависят от объема финансирования ученых, который является ключевым вопросом функционирования и развития аграрной науки. Недостаточный объем финансирования не позволяет установить высокий уровень заработной платы научным работникам, ограничена возможность финансирования повышения их квалификации, соответственно, сфера науки не привлекательна для молодых ученых.

В настоящее время объем финансирования аграрной науки Казахстана составляет 0,15 \% от валовой продукции сельского хозяйства. В 2018 г. он увеличился за счет дополнительного программно целевого финансирования в объеме 3,39 млрд тенге. В соответствии с Государственной программой развития АПК на 2017-2021 годы планируется доведение финансирования аграрной науки к 2030 г. до $1 \%$ от объема валовой продукции сельского хозяйства, в том числе до 0,5\% в 2021 г.

Для сравнения, в 1991 г. объем финансирования аграрной науки составлял 1,2 \% от объема валовой продукции сельского хозяйства. Также, согласно рекомендациям Международного академического совета, доля расходов на науку среди развивающихся стран должна быть около 1,0-1,5 \% ВВП. К примеру, в настоящее время доля расходов к ВВП страны на всю науку в Японии составляет $3,3 \%$, США-2,8, Германии - 2,5, Китае-1,4, России - 1,3, Казахстане-0,2 \%, в том числе аграрной науки $-0,14 \%$.

Таким образом, объем финансирования аграрной науки в стране крайне низкий, при том что Казахстан стремится войти в 30-ку самых развитых стран мира, что невозможно без развитой научной системы, включающей и аграрную науку, удельный вес которой в валовой продукции сельского хозяйства должен быть не ниже 1,5-2,0 \%.

Объективная необходимость обеспечения качества казахстанского высшего образования в соответствии с мировыми стандартами, повышение его привлекательности и конкурентоспособности в рамках Болонского процесса очевидна. Вместе с тем, как показывает 7-летняя практика действия в Казахстане болонской системы 
образования, упразднение классической аспирантуры и докторантуры в научных организациях, перенос центра подготовки научных кадров высшей квалификации в вузы привело к снижению уровня подготовки таких кадров и возможности формирования молодого поколения исследователей. Из трех аграрных вузов практически нет притока докторов $\mathrm{PhD}$ в НИИ. Практически все научные исследования в сфере АПК проводятся учеными, защитившими кандидатские и докторские диссертации еще при прежней классической системе послевузовского образования, что свидетельствует о ее эффективности. Возможно, это обусловлено тем, что в вузах пока нет четко функционирующей научной школы, сформировавшейся модели эффективной научноисследовательской работы. Кроме того, качество ранее практикуемых кандидатских и докторских диссертаций несравнимо с качеством диссертации доктора $\mathrm{PhD}$. К примеру, требование диссертационной работы на соискание ученой степени доктора наук состояло в постановке и разрешении важной научной проблемы, которая обладает немаловажным социальным или экономическим значением. Диссертационные советы действовали в НИИ, подготовка аспирантов и докторантов велась в профессиональной научной среде, что в результате способствовало эффективному обеспечению аграрной науки высококвалифицированными научными кадрами.

В связи с этим представляется целесообразным ввести четырехуровневую систему высшего образования: бакалавр - магистр - PhD-хабилитированный доктор. Это не противоречит Болонской системе образования и в то же время позволит сформировать высокопрофессиональный состав молодых исследователей в научных организациях. В этих целях следует восстановить в НИИ диссертационные советы и подготовку докторов наук.

Социальные условия ученых определены в Законе Республики Казахстан «О науке». Это вопросы оплаты труда, предоставления отпусков, создания жилищных условий. В отношении НИИ аграрной сферы в этом аспекте играет существенную роль их статус как научных организаций, приравненных к государственным. Однако недостаточное финансирование науки не позволяет устанавливать высокую заработную плату научным работникам, соответствующую их профессиональной квалификации. Соответственно, вопрос материального стимулирования именно молодых ученых стоит очень остро, ведь они вынуждены искать другие источники дохода. Им нужно содержать семьи, выплачивать ипотеку, потребительские кредиты.

В большинстве случаев компетентными государственными органами в вопросе жилищного обеспечения в отношении работников научных организаций аграрного профиля, имеющих статус ТОО, норма Закона «О науке» о равенстве их статуса с государственными игнорируется. В этих целях следует обратить внимание государственных органов на соблюдение норм законодательства о социальной поддержке ученых и разработать более действенный механизм реализации такой поддержки.

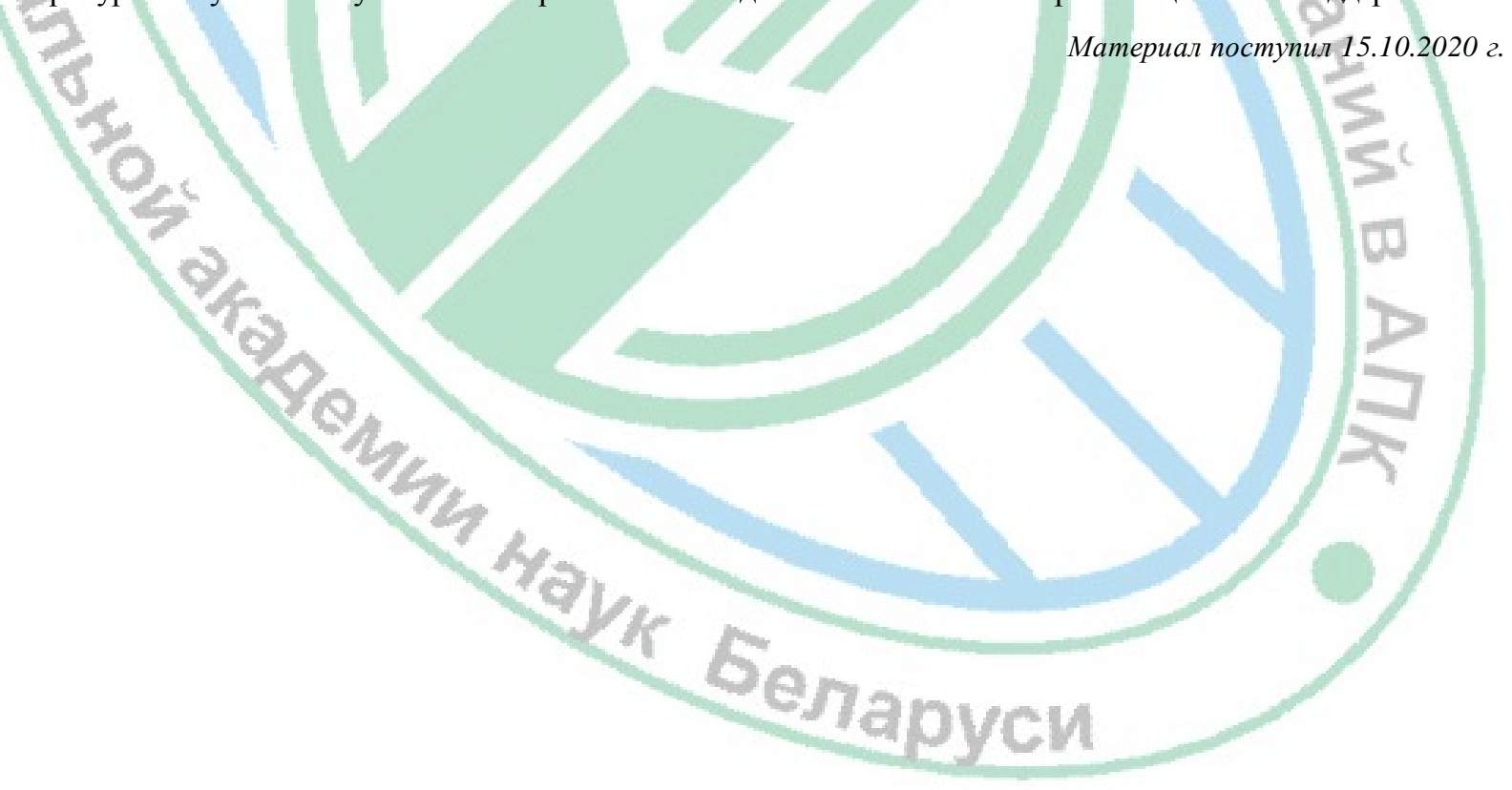

